\title{
FACTOR CONTRIBUTING TO PARENTAL AWARENESS OF CHILDHOOD OBESITY AMONG THAI PRESCHOOL CHILDREN
}

\author{
Jittima Rodsawad, Lertchai Charerntanyarak, Benjawan Tawatsupa \\ Health Impact Assessment Division, Department of Health, Ministry of Public Health \\ Tiwanon Road, Muang District, Nonthaburi 11000,Thailand \\ jrodsawad@gmail.com \\ Faculty of Public Health, Department of Epidemiology, Khon Kaen University \\ 123 Mittrapap Road, Amphur Muang, Khon Kaen Province 42000, Thailand \\ lertchai@kku.ac.th, lertchai2499@gmail.com \\ Health Impact Assessment Division, Department of Health, Ministry of Public Health \\ Tiwanon Road, Muang District, Nonthaburi 11000,Thailand
}

ben_5708@hotmail.com

\begin{abstract}
Thailand is undergoing nutritional transition from replacement of underweight to high prevalence of overweight and obesity in children. Family environment play critical role for successful prevention in childhood obesity. This study aims to determine factors contributing to awareness about childhood obesity among the parents and guardians of preschool children in an urban area of Nakon Prathom province, Thailand. A cross-sectional survey was conducted among 588 parents or guardians of preschool children at levels 1 and 2 of a kindergarten school. Data were collected using a selfadministered questionnaire. Logistic regression was used to analyze related factors and covariates influencing parental awareness. A total of $495(84.2 \%)$ completed questionnaires. Parental awareness was significantly associated to their education level and their beliefs regarding various approaches to combating childhood obesity. A number of demographic variables (age, household monthly income, family caregiver) had no statistically significant associations with parental awareness. The study indicated that incorrect beliefs increased the risk of low parental awareness about childhood obesity. Health education should be provided to increase knowledge of parents and guardians about ways of dealing with the problems of obesity and to help them to maintain healthy weights in their children.
\end{abstract}

\section{Keywords}

childhood, obesity, parental awareness, Thai preschool children

\section{Academic Discipline And Sub-Disciplines}

Sociology

TYPE (METHOD/APPROACH)

Survey

\section{Council for Innovative Research}

Peer Review Research Publishing System

Journal: Journal of Social Sciences Research

Vol .6, No.3

jssreditor.cir@gmail.com

www.jssronline.com 


\section{INTRODUCTION}

In the past few decades the prevalence of childhood overweight and obesity has escalated dramatically in developing countries (Sakamoto, Wansorn, Tontisirin, \& Marui, 2001). Thailand has also been faced with this problem due to social and economic transition (Kosulwat, 2001). Children aged $0-72$ months with overweight and obesity were $2.9 \%$ in 2009 and up to more than three times (9.7\%) in 2011. Moreover children aged between 6 and 18 years with overweight and obesity were $6.9 \%$ in 2010 and rapidly increase to $9.0 \%$ in 2011 .

As the prevalence of childhood obesity is associated with a significant risk of adverse health consequences and comorbidities in adulthood early prevention or intervention is therefore required to decrease the health implications (Dietz \& Robinson, 2005; Reilly et al., 2003). The cultural and family environment can often be seen as responsible for the development of childhood overweight and obesity (Golan \& Crow, 2004).

Parents play a critical role in influencing family attitude towards healthy eating and physical activity. Increasing parental awareness can help to prevent overweight and obesity in children (Arredondo et al., 2006; Birch \& Fisher, 2000; Eckstein et al., 2006; Hesketh, Waters, Green, Salmon, \& Williams, 2005; Johannsen, Johannsen, \& Specker, 2006; Stanton et al., 2004; Vanhala, Keinanen-Kiukaanniemi, Kaikkonen, Laitinen, \& Korpelainen, 2011). The aim of this study was to identify factors associated with parental awareness of the problems of overweight and obesity in Thai preschool children.

\section{METHODS}

The study was conducted during 2012 in a kindergarten school located in an urban area of Nakon Prathom Province, Thailand. The subjects were the parents or guardians of kindergarten students aged 4-6 years at level 1 and level 2, and written informed consent was completed prior to their participation. This study was approved by the Ehics Committee for Research in Human Subjects, Department of Disease Control.

A self-administered questionnaire was distributed to the parents or guardians of the children by a classroom teacher and completed questionnaires were collected one were later, The participants were asked to provide information about demographic characteristics (sex, status, age, education level, household monthly income and family caregiver). They were also asked about the frequency (often, sometimes, never) of skipping breakfast, eating junk food and beverages and spending family time outdoor activities. Additional items were included to assess beliefs about approached to combating childhood obesity. This involved asking participants whether they agreed or disagreed (yes, no) with each of four statements: 'a healthy child refers to child those who is healthy only in physical aspects', 'Monitoring child growth development is a teacher responsibility', 'healthy practices in children should be encouraged in their preschool years rather than later when they are at school', and 'rewarding child with candies can make them prefer these to vegetables'. The dependent variable of parental awareness of the problems of overweight and obesity was assessed by asking participants to agree or disagree with two statements. 'excess weight in childhood will not persist in adulthood' and 'overweight or obesity in childhood is not a serious problem'.

The data were analysed using SPSS version 19.0 for Windows and Stata 12. Cross tabulation and chi-square were used in an initial exploration of factors related to parental awareness. The associations between each of potential contributing factors and parental awareness were assessed by a univariate analysis, which yielded crude odds ratios (ORs) were then adjusted for the influence of all contributing factors (sex, marital status, age, education level, household monthly income, family caregiver, skipping breakfast, eating junk food and beverages and spending family time in outdoor activity, and the four variables about beliefs related to combating childhood obesity). Finally, using a stepwise logistic regression was performed included on significant contributing factors $(p$-value $\leq 0.05)$

\section{RESULTS}

Of the 588 parents or guardians who agreed to participated in this study, 495 (84.2\%) completed the questionnaires. The characteristics of the respondents are summarized in Table 1 . The majority (74.3\%) were female and $37.6 \%$ reported a household income in the range of 10,001-20,000 baht per month. Not many (8.8\%) of them were educated beyond the bachelor degree level. More than half of respondents (63.4\%) believed that excess weight in childhood will persist in adulthood. There was a strong statistically significant association between education level and parental awareness of this $(p<0.001)$. Furthermore, a large majority of respondents $(88.3 \%)$ reported disagreement with the statement that childhood overweight or obesity is not a serious health problem. Similarly, education level was found to be significantly related to parental awareness $(p<0.05)$. However, there were no statistically significant associations between demographic variables (age, household monthly income, family caregiver) and parental awareness. Parental beliefs about ways to combat overweight and obesity were found to have strong statistically significant relationship with both the two measures of parental awareness. Interestingly, the belief that healthy practices should be encouraged in preschoolers rather than when the children have reached school age was held by only $15.2 \%$ of the respondents and was significantly associated ( $p \leq 0.001)$ with low levels of awareness. 
Table 1 Characteristics of respondents $(N=495)$

\begin{tabular}{|c|c|c|c|c|c|c|c|c|c|}
\hline & & \multicolumn{3}{|c|}{$\begin{array}{l}\text { Agreed with 'Excess weight } \\
\text { in childhood will not persist } \\
\text { in adulthood' }\end{array}$} & \multicolumn{3}{|c|}{$\begin{array}{l}\text { Agreed with 'Overweight or } \\
\text { obesity in childhood is not } \\
\text { a serious problem' }\end{array}$} & \multicolumn{2}{|c|}{ Total } \\
\hline & & $\mathbf{N}$ & $\%$ & $\begin{array}{l}\text { P-value } \\
\left(\mathrm{Chi}^{2}\right)\end{array}$ & $\mathbf{N}$ & $\%$ & $\begin{array}{l}\text { P-value } \\
\left(\text { Chi }^{2}\right)\end{array}$ & $\mathbf{N}$ & $\%$ \\
\hline \multicolumn{2}{|c|}{ Demographic Profile } & 181 & 36.6 & & 58 & 11.7 & & 495 & 100.0 \\
\hline \multirow[t]{2}{*}{ Sex } & Male & 34 & 18.8 & 0.008 & 15 & 25.9 & 0.970 & 127 & 25.7 \\
\hline & Female & 147 & 81.2 & & 43 & 74.1 & & 368 & 74.3 \\
\hline \multirow[t]{3}{*}{ Marital Status } & Single & 9 & 5.0 & 0.776 & 7 & 12.1 & 0.039 & 26 & 5.3 \\
\hline & Married & 160 & 88.4 & & 48 & 82.8 & & 431 & 87.1 \\
\hline & Divorced/Widowed & 12 & 6.6 & & 3 & 5.2 & & 38 & 7.7 \\
\hline \multirow[t]{3}{*}{ Age } & $16-25$ yrs & 12 & 6.6 & 0.171 & 3 & 5.2 & 0.264 & 22 & 4.4 \\
\hline & $26-35$ yrs & 78 & 43.1 & & 30 & 51.7 & & 210 & 42.4 \\
\hline & $\geq 36 \mathrm{yrs}$ & 91 & 50.3 & & 25 & 43.1 & & 263 & 53.1 \\
\hline \multirow[t]{3}{*}{ Education } & Less than bachelor & 106 & 58.6 & $<0.001$ & 36 & 62.1 & 0.004 & 232 & 46.9 \\
\hline & Bachelor & 66 & 36.5 & & 14 & 24.1 & & 219 & 44.2 \\
\hline & Higher than bachelor & 9 & 5.0 & & 8 & 13.8 & & 44 & 8.9 \\
\hline \multirow{4}{*}{$\begin{array}{l}\text { Household } \\
\text { monthly income }\end{array}$} & $<10,000$ baht & 42 & 23.2 & 0.063 & 14 & 24.1 & 0.337 & 87 & 17.6 \\
\hline & $10,001-20,000$ baht & 66 & 36.5 & & 17 & 29.3 & & 186 & 37.6 \\
\hline & $20,001-30,000$ baht & 39 & 21.6 & & 15 & 25.9 & & 109 & 22.0 \\
\hline & $>30,001$ baht & 34 & 18.8 & & 12 & 20.7 & & 113 & 22.8 \\
\hline \multirow{3}{*}{$\begin{array}{l}\text { Family } \\
\text { caregiver }\end{array}$} & Parents & 75 & 41.4 & 0.134 & 25 & 43.1 & 0.075 & 234 & 47.3 \\
\hline & Mother /Father & 76 & 42.0 & & 19 & 32.8 & & 190 & 38.4 \\
\hline & Cousin & 30 & 16.6 & & 14 & 24.1 & & 71 & 14.3 \\
\hline \multicolumn{10}{|c|}{ Family Eating and Activity Pattern } \\
\hline \multirow[t]{3}{*}{ Skip Breakfast } & Often & 53 & 29.3 & 0.036 & 15 & 25.9 & 0.513 & 114 & 23.0 \\
\hline & Sometimes & 50 & 27.6 & & 19 & 32.8 & & 141 & 28.5 \\
\hline & Never & 78 & 43.1 & . & 24 & 41.4 & & 240 & 48.5 \\
\hline \multirow[t]{3}{*}{ Junk Food } & Often & 8 & 4.4 & 0.380 & 7 & 12.1 & 0.026 & 26 & 5.3 \\
\hline & Sometimes & 153 & 84.5 & & 44 & 75.9 & & 425 & 85.9 \\
\hline & Never & 20 & 11.1 & & 7 & 12.1 & & 44 & 8.9 \\
\hline \multirow[t]{3}{*}{ Beverages } & Often & 57 & 31.5 & 0.860 & 28 & 48.3 & 0.025 & 163 & 32.9 \\
\hline & Sometimes & 115 & 63.5 & & 27 & 46.6 & & 309 & 62.4 \\
\hline & Never & 9 & 5.0 & & 3 & 5.2 & & 23 & 4.7 \\
\hline \multirow{3}{*}{$\begin{array}{l}\text { Spending family } \\
\text { time in outdoor } \\
\text { activities }\end{array}$} & Often & 4 & 2.2 & 0.851 & 4 & 6.9 & 0.036 & 11 & 2.2 \\
\hline & Sometimes & 68 & 37.6 & & 21 & 36.2 & & 194 & 39.2 \\
\hline & Never & 109 & 60.2 & & 33 & 56.9 & & 290 & 58.6 \\
\hline \multicolumn{10}{|c|}{ Belief related to measure combating childhood obesity } \\
\hline \multirow{2}{*}{$\begin{array}{l}\text { A healthy child } \\
\text { refers to child } \\
\text { those who is } \\
\text { healthy only in } \\
\text { physical } \\
\text { aspects }\end{array}$} & Yes & 28 & 15.5 & $<0.001$ & 12 & 20.7 & $<0.001$ & 35 & 7.1 \\
\hline & No & 153 & 84.5 & & 46 & 79.3 & & 460 & 92.9 \\
\hline
\end{tabular}




\begin{tabular}{|c|c|c|c|c|c|c|c|c|c|}
\hline \multirow{2}{*}{$\begin{array}{l}\text { Monitoring Child } \\
\text { growth } \\
\text { development is } \\
\text { a teacher } \\
\text { responsibility }\end{array}$} & Yes & 24 & 13.3 & \multirow[t]{2}{*}{$<0.001$} & 9 & 15.5 & \multirow[t]{2}{*}{0.017} & 38 & 7.7 \\
\hline & No & 157 & 86.7 & & 49 & 84.5 & & 457 & 92.3 \\
\hline \multirow[b]{2}{*}{$\begin{array}{l}\text { Healthy } \\
\text { practices in } \\
\text { children should } \\
\text { be encouraged } \\
\text { in their } \\
\text { preschool years } \\
\text { rather than later } \\
\text { when they are } \\
\text { at school }\end{array}$} & Yes & 43 & 23.8 & \multirow[t]{2}{*}{$<0.001$} & 19 & 32.8 & \multirow[t]{2}{*}{$<0.001$} & 75 & 15.2 \\
\hline & No & 138 & 76.2 & & 39 & 67.2 & & 420 & 84.9 \\
\hline \multirow{2}{*}{$\begin{array}{l}\text { Rewarding child } \\
\text { with candies } \\
\text { can make them } \\
\text { prefer these to } \\
\text { vegetables }\end{array}$} & Yes & 39 & 21.6 & \multirow[t]{2}{*}{0.004} & 20 & 34.5 & \multirow[t]{2}{*}{$<0.001$} & 76 & 15.4 \\
\hline & No & 142 & 78.5 & & 38 & 65.5 & & 419 & 84.7 \\
\hline
\end{tabular}

Table 2 shows association between potential contributing factors and parental awareness. Crude ORs were computed for the associations between each measure of parental awareness about childhood obesity and each of the contributing factors. The results revealed that females were less likely than males to disagree with 'excess weight gain persist into adulthood' which means that, compared with males, females have less awareness regarding to excess weight gain persisting into adulthood (crude OR $=0.54$ ).

Table 2 Univariate analysis (crude ORs) of associations between each of potential contributing factors and parental awareness

\begin{tabular}{|c|c|c|c|c|c|c|c|c|c|}
\hline & & \multicolumn{4}{|c|}{$\begin{array}{l}\text { Agreed with 'Excess weight in } \\
\text { childhood will not persist in } \\
\text { adulthood' }\end{array}$} & \multicolumn{4}{|c|}{$\begin{array}{l}\text { Agreed with 'Overweight or obesity } \\
\text { in childhood is not a serious } \\
\text { problem' }\end{array}$} \\
\hline & & $\begin{array}{l}\text { Crude } \\
\text { OR† }\end{array}$ & P-value & $95 \%$ & & $\begin{array}{l}\text { Crude } \\
\text { ORt }\end{array}$ & P-value & $95^{\circ}$ & \\
\hline \multirow[t]{2}{*}{ Sex } & Male & 1 & & & & 1 & & & \\
\hline & Female & $0.54^{*}$ & 0.007 & $0.35-$ & 0.84 & 1.02 & 0.962 & $0.54-$ & 1.90 \\
\hline \multirow[t]{3}{*}{ Marital Status } & Single & 1 & & & & 1 & & & \\
\hline & Married & 0.89 & 0.788 & 0.39 & 2.05 & $2.79^{*}$ & 0.027 & $1.12-$ & 6.95 \\
\hline & Divorced/Widowed & 1.19 & 0.745 & $0.41-$ & 3.42 & 4.08 & 0.059 & $0.95-$ & 17.58 \\
\hline \multirow[t]{3}{*}{ Age } & $16-25$ yrs & & & & & 1 & & & \\
\hline & $26-35$ yrs & 2.02 & 0.119 & $0.83-$ & 4.89 & 0.95 & 0.934 & $0.26-$ & 3.40 \\
\hline & $\geq 36$ yrs & 2.27 & 0.067 & $0.94-$ & 5.45 & 1.51 & 0.53 & $0.42-$ & 5.46 \\
\hline \multirow[t]{3}{*}{ Education } & Less than bachelor & 1 & & & & 1 & & & \\
\hline & Bachelor & $1.90^{*}$ & 0.001 & $1.30-$ & 2.79 & $2.68^{*}$ & 0.003 & $1.40-$ & 5.11 \\
\hline & Higher than bachelor & $3.25^{\star}$ & 0.003 & $1.49-$ & 7.06 & 0.82 & 0.65 & $0.35-$ & 1.91 \\
\hline \multirow{4}{*}{$\begin{array}{l}\text { Household } \\
\text { monthly income }\end{array}$} & $<10,000$ baht & 1 & & & & 1 & & & \\
\hline & $10,001-20,000$ baht & 1.64 & 0.061 & $0.98-$ & 2.73 & 1.88 & 0.103 & $0.88-$ & 4.01 \\
\hline & $20,001-30,000$ baht & 1.64 & 0.091 & $0.92-$ & 2.91 & 1.19 & 0.673 & $0.54-$ & 2.61 \\
\hline & $>30,001$ baht & 2.11 & 0.011 & $1.19-$ & 3.76 & 1.59 & 0.27 & $0.70-$ & 3.64 \\
\hline \multirow{3}{*}{$\begin{array}{l}\text { Family } \\
\text { caregiver }\end{array}$} & Parents & 1 & & & & 1 & & & \\
\hline & Mother/Father & 0.69 & 0.068 & $0.46-$ & 1.03 & 1.08 & 0.818 & $0.57-$ & 2.02 \\
\hline & Cousin & 0.66 & 0.128 & $0.38-$ & 1.13 & 0.50 & 0.055 & $0.24-$ & 1.01 \\
\hline
\end{tabular}




\begin{tabular}{|c|c|c|c|c|c|c|c|c|c|}
\hline \multirow[t]{3}{*}{ Skip Breakfast } & Often & \multicolumn{4}{|l|}{1} & \multicolumn{4}{|l|}{1} \\
\hline & Sometimes & 1.59 & 0.071 & $0.96-$ & 2.63 & 0.98 & 0.958 & $0.47-$ & 2.03 \\
\hline & Never & $1.73^{*}$ & 0.018 & $1.10-$ & 2.73 & 1.36 & 0.377 & $0.69-$ & 2.71 \\
\hline \multirow[t]{3}{*}{ Junk food } & Often & 1 & & & & 1 & & & \\
\hline & Sometimes & 0.74 & 0.496 & $0.32-$ & 1.74 & $3.19^{\star}$ & 0.014 & $1.27-$ & 8.01 \\
\hline & Never & 0.51 & 0.188 & $0.18-$ & 1.40 & 2.00 & 0.251 & $0.61-$ & 6.53 \\
\hline \multirow[t]{3}{*}{ Beverages } & Often & 1 & & & & 1 & & & \\
\hline & Sometimes & 0.93 & 0.715 & $0.63-$ & 1.38 & $2.17^{\star}$ & 0.007 & $1.23-$ & 3.83 \\
\hline & Never & 0.85 & 0.725 & $0.35-$ & 2.09 & 1.38 & 0.62 & $0.38-$ & 4.97 \\
\hline \multirow{3}{*}{$\begin{array}{l}\text { Spending family } \\
\text { time in outdoor } \\
\text { activities }\end{array}$} & Often & 1 & & & & 1 & & & \\
\hline & Sometimes & 1.06 & 0.928 & $0.30-$ & 3.75 & $4.71^{*}$ & 0.02 & $1.27-$ & 17.43 \\
\hline & Never & 0.95 & 0.93 & $0.27-$ & 3.30 & $4.47^{\star}$ & 0.022 & $1.24-$ & 16.08 \\
\hline \multirow{2}{*}{$\begin{array}{l}\text { A healthy child } \\
\text { refer to child } \\
\text { those who is } \\
\text { healthy only in } \\
\text { physical } \\
\text { aspects }\end{array}$} & Yes & 1 & & & & 1 & & & \\
\hline & No & $8.00^{* *}$ & $<0.001$ & 3.42 - & 18.72 & $4.71^{* *}$ & $<0.001$ & $2.20-$ & 10.08 \\
\hline $\begin{array}{l}\text { Monitoring Child } \\
\text { growth } \\
\text { development is } \\
\text { a teacher } \\
\text { responsibility }\end{array}$ & $\begin{array}{l}\text { Yes } \\
\text { No }\end{array}$ & $\begin{array}{l}1 \\
3.27^{\star \star}\end{array}$ & 0.001 & 1.6 & 6.49 & $\begin{array}{l}1 \\
2.59^{*}\end{array}$ & 0.02 & $1.16-$ & 5.79 \\
\hline $\begin{array}{l}\text { Healthy } \\
\text { practices in } \\
\text { children should } \\
\text { be encouraged } \\
\text { in their } \\
\text { preschool years } \\
\text { rather than later } \\
\text { when they are } \\
\text { at school }\end{array}$ & $\begin{array}{l}\text { Yes } \\
\text { No }\end{array}$ & $\begin{array}{l}1 \\
2.82^{* *}\end{array}$ & $<0.001$ & 1.71 & 4.64 & $\begin{array}{l}1 \\
3.32^{* *}\end{array}$ & $<0.001$ & $1.80-$ & 6.15 \\
\hline $\begin{array}{l}\text { Rewarding child } \\
\text { with candies } \\
\text { can make them } \\
\text { prefer these to } \\
\text { vegetables }\end{array}$ & $\begin{array}{l}\text { Yes } \\
\text { No }\end{array}$ & $\begin{array}{l}1 \\
2.05\end{array}$ & 0.004 & 1.25 & 3.35 & $3.52^{* *}$ & $<0.001$ & $1.91-$ & 6.47 \\
\hline
\end{tabular}

† Associations with contributing factor and parental awareness each expressed as crude odds ratios (Crude ORs), $\left({ }^{*} P\right.$-value $\left.<0.05\right) \&\left({ }^{* *} P\right.$-value $\left.<0.001\right)$

Parents who graduated with bachelor and higher degrees were more likely than parents with a lower educational attainment to disagree (or have more awareness) regarding excess weight gain persisting into adulthood when compared parents who have lower education level (crude ORs $=1.90$ and 3.25, respectively). In addition, parents who never or only sometimes spent family time in outdoor activity were more likely to disagree with the statement 'overweight or obesity in childhood is not a serious problem' which means they had more awareness about childhood obesity compared with those who often spent family time in outdoor activity (crude ORs $=4.47$ and 4.41 , respectively). Moreover, parents who had correct beliefs about ways of combating childhood obesity had higher parental awareness than those with incorrect beliefs. 
Table 3 Multivariate analysis (adjusted ORs) for association between all contributing factors and parental awareness

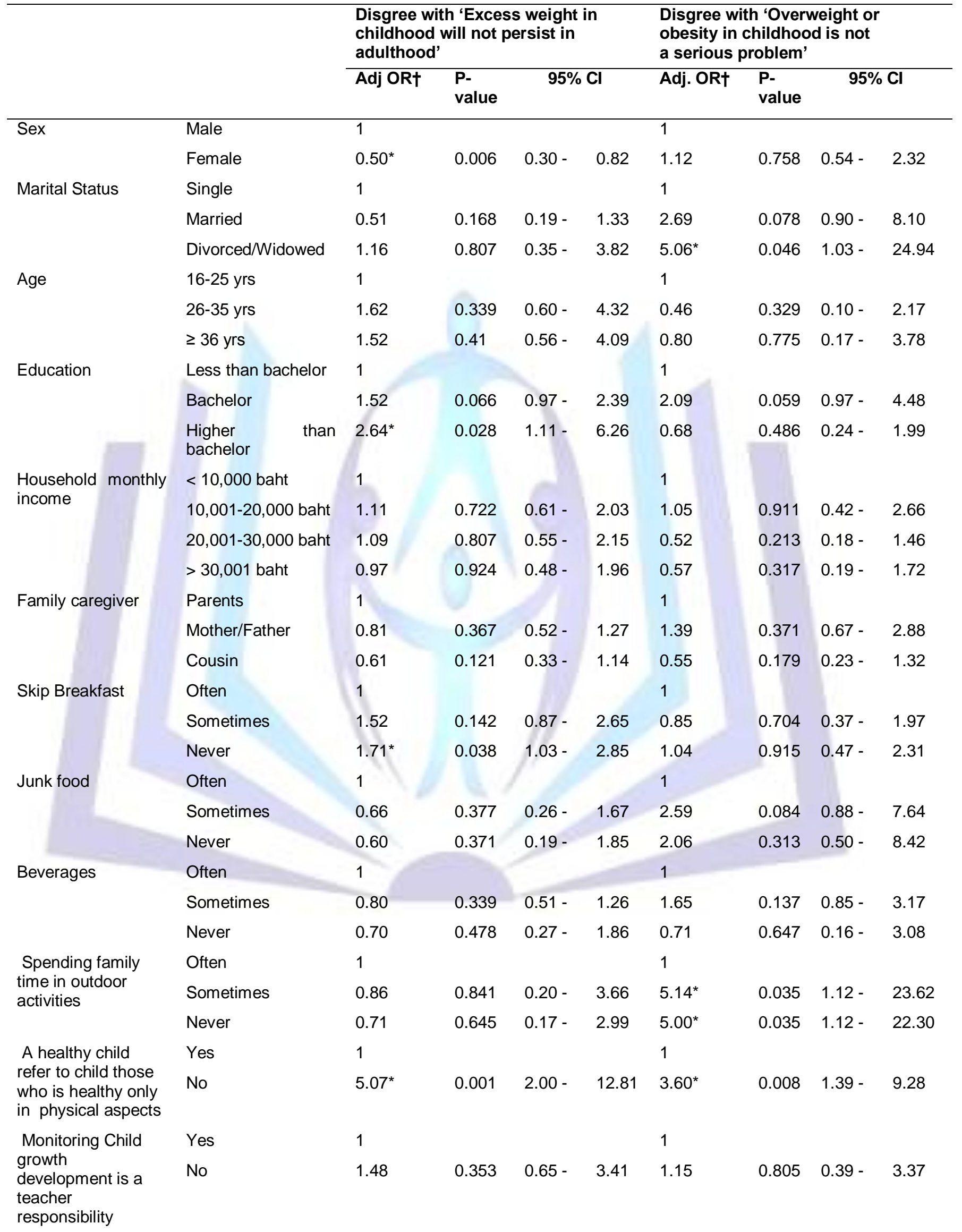


Healthy practices in children should be encouraged in their preschool years rather than later when they are at school
Yes No $1.96 *$
0.026

$1.08-$
$0.083 \quad 0.91-$

4.41
Rewarding child with candies can make them prefer these to vegetables
Yes No
1.62

$0.93-$

2.83

2.01

$\lceil$ The adjusted odds ratios (Adj. ORs) show estimates for the associations adjusted for all other contributing factors (sex, status, age, education level, household monthly income, family caregiver, skipping breakfast, eating junk food and beverages and spending family time for outdoor activities, and the four variables about belief related to measure combating childhood obesity). $\left({ }^{\star} P\right.$-value $\left.<0.05\right) \&\left({ }^{\star *} P\right.$-value $\left.<0.001\right)$

Table 3 shows the associations between all contributing factors and parental awareness using multivariate logistic regression. Adjusted ORs were computed for the associations between each measure of parental awareness and each covariate. Overall, the results revealed that sex, parent's education level and spending family time in outdoor activity were important factors which can influence awareness of excess weight gain persisting into adulthood. In additions, marital status and spending family time in outdoor activity can influence awareness that overweight or obesity in childhood is a serious problem.

Finally, Table 4 shows the associations between contributing factors and parental awareness using stepwise logistic regression. Only the factors found to have statistically significant associations with parental awareness in the previous analysis (adjusted ORs) were included in the stepwise analysis. This final models confirms our previous results that sex, education level, and two variables about beliefs related to combating childhood obesity ('a healthy child refers to child those who is health only in physical aspects' and 'healthy practices in children should be encouraged in their preschool years rather than later when they are at school' can influence the parent's awareness that 'excess weight in childhood will not persist in adulthood' The stepwise model also showed the same pattern regarding education level. The parents who had higher education were more likely to disagree with the statement that 'excess weight in childhood will not persist in adulthood' (they have higher awareness). Marital status, education level, spending family time in outdoor activity, and the three variables about beliefs related to combating childhood obesity were all factors which had a significant association with parental awareness about 'overweight or obesity in childhood is not a serious problem'.

Table 4 Stepwise multivariate analysis (stepwise ORs) for association between all significant contributing factors and parental awareness

\begin{tabular}{|c|c|c|c|c|c|c|c|}
\hline & & \multicolumn{3}{|c|}{$\begin{array}{l}\text { Disagree with 'Excess weight in } \\
\text { childhood will not persist in } \\
\text { adulthood' }\end{array}$} & \multicolumn{3}{|c|}{$\begin{array}{l}\text { Disagree with 'Overweight or obesity } \\
\text { in childhood is not a serious problem' }\end{array}$} \\
\hline & & Stepw OR† & $\begin{array}{l}\text { P- } \\
\text { Value }\end{array}$ & $95 \% \mathrm{Cl}$ & Stepw OR†† & $\begin{array}{l}\text { P- } \\
\text { Value }\end{array}$ & $95 \% \mathrm{Cl}$ \\
\hline \multirow[t]{5}{*}{ Sex } & Male & 1 & & & - & & \\
\hline & Female & 0.51 & 0.005 & .82 & & & \\
\hline & Single & & & & 1 & & \\
\hline & Married & & & & $3.31^{*}$ & 0.020 & $1.21-9.05$ \\
\hline & Divorced/Widowed & & & 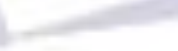 & $6.64^{*}$ & 0.018 & $1.39-31.73$ \\
\hline \multirow[t]{3}{*}{ Education } & Less than bachelor & 1 & & & 1 & & \\
\hline & Bachelor & $1.66^{*}$ & 0.015 & $1.11-2.49$ & $1.99^{*}$ & 0.05 & $1.00-3.94$ \\
\hline & $\begin{array}{l}\text { Higher } \\
\text { bachelor }\end{array}$ & $2.72^{*}$ & 0.014 & $1.23-6.04$ & 0.55 & 0.203 & $0.22-1.38$ \\
\hline \multirow{3}{*}{$\begin{array}{l}\text { Spending family } \\
\text { time in outdoor } \\
\text { activities }\end{array}$} & Often & - & & & 1 & & \\
\hline & Sometimes & & & & $7.06^{\star *}$ & 0.007 & $1.71-29.18$ \\
\hline & Never & & & & $6.17^{\star \star}$ & 0.010 & $1.55-24.55$ \\
\hline \multirow{2}{*}{$\begin{array}{l}\text { A healthy child } \\
\text { refer to child } \\
\text { those who is } \\
\text { healthy only in } \\
\text { physical } \\
\text { aspects }\end{array}$} & Yes & 1 & & & 1 & & \\
\hline & No & $5.67^{\star \star \star}$ & $\begin{array}{l}<0.00 \\
1\end{array}$ & $\begin{array}{l}2.34 \\
13.75\end{array}$ & $2.78^{*}$ & 0.023 & $1.15-6.68$ \\
\hline
\end{tabular}


Healthy practices in children should be encouraged in their preschool years rather than later when they are at school

Rewarding child with candies can make them prefer these to vegetables
Yes No 1 $2.03^{*}$

† The stepwise odds ratios (Stepw ORs) for estimating the significant contributing factors on 'Excess weight in childhood will not persist in adulthood' includes all statistically significant factors (sex, education level, and two variables about belief related to measure combating childhood obesity:; 'A healthy child refer to child those who is healthy only in physical aspects' and 'Healthy practices in children should be encouraged in their preschool years rather than later when they are at school').

†† The stepwise odds ratios (Stepw ORs) for estimating the significant contributing factors on 'Overweight or obesity in childhood is not a serious problem' includes all statistically significant factors (marital status, education level, spending family time in outdoor activity, and three variables about belief related to measure combating childhood obesity).

$\left({ }^{*}\right.$ P-value $\left.<0.05\right) \&\left({ }^{* *} P\right.$-value $\left.<0.001\right)$

\section{DISCUSSION}

In this study, it was found that a respondent's education level was significantly associated with parental awareness about childhood obesity. The ORs showed that the higher the educational level of the parent/guardian the more likely that he or she was to reject the idea that excess weight in children does not persist into adulthood. This finding confirms those of previous studies which show that education level impacts on the awareness of parents about overweight and obesity in their children (Birch \& Fisher, 2000; Clark, Goyder, Bissell, Blank, \& Peters, 2007). Many studies have reported that low awareness among parents may be a risk factor for childhood obesity (Clark et al., 2007; Golan \& Crow, 2004; Hesketh et al., 2005). Additionally, the present study found a relationship between parental beliefs regarding combating obesity in children and parental awareness about childhood obesity. Incorrect beliefs about combating were risk factors for a low awareness about childhood obesity. This may be due to the fact that Thailand has been faced with a nutritional transition in only recent decades (2), and that parental beliefs and awareness regarding childhood obesity have not been given much attention in the wider society. Hence, in order to deal with the obesity problem and help to maintain healthy weights in children, it suggested that health education should be provided to increase the knowledge of parents who have low awareness.

Various limitations in this study should be considered. Firstly, the study population was recruited using a convenience sample of participants and selection biases may therefore have effected the results. Secondly, no attempt was made to measure the weight status of the children of the respondents as was done in previous studies. These data would have strengthened the conclusions about factors related to parental awareness. Thirdly, this research was undertaken in an urban area of Nakhon Prathom Province, and the results may not generalize to other populations of preschool children. Fourthly, this was a cross-sectional study, and the results can therefore only be interpreted as those applying at the single point of time when the data were collected. Nevertheless, only a few previous studies were found which investigated culture aspects regarding childhood obesity in a Thai context, and most of these focused on school age children. The findings of this study may be beneficial for the planning of further studies of preschool children in Thailand.

\section{CONCLUSION}

This study explored the factors contributing to parental awareness regarding childhood obesity. A statistically significant association was found between parental beliefs and awareness. Increasing public awareness and health education may help parents understand health issues related to childhood obesity and in particular, their role in the establishment of healthy behaviors in their children. Effective approaches to the solutions to the problem of overweight and obesity in early childhood are needed for the successful long term maintenance of healthy weight in older children.

\section{ACKNOWLEDGEMENT}

The authors would like to thank all the participating parents or guardians, the administrative, and teaching staffs of Nakhon Prathom Kindergarten School, the Provincial Chief Medical Officer of Nakhon Prathom Province (Dr. Kongdej Leethochaowalit) and the Provincial Health Assembly (Mr. Prachern Konthet) for coordination and contribution. And I would like to give special thanks to Dr. Peter Bradshaw for English language technical editing. This work was supported by a grant from the Thai Health Promotion Foundation (Contract No. 53-00-1221. Project Code 53-01646) 


\section{REFERENCES}

1. Sakamoto N, Wansorn S, Tontisirin K, Marui E. A social epidemiologic study of obesity among preschool children in Thailand. International Journal Obesity. 2001;25:389-94.

2. Kosulwat V. The nutrition and health transition in Thailand. Public Heath Nutrition. 2001;5(1A):183-9.

3. Dietz WH, Robinson TN. Clinical practice. Overweight children and adolescents. N Engl J Med. 2005 May 19;352(20):2100-9.

4. Reilly JJ, Methven E, McDowell ZC, Hacking B, Alexander D, Stewart L, et al. Health consequences of obesity. Arch Dis Child. 2003 Sep;88(9):748-52.

5. Golan M, Crow S. Parents are key players in the prevention and treatment of weight-related problems. Nutr Rev. 2004 Jan;62(1):39-50.

6. Arredondo EM, Elder JP, Ayala GX, Campbell N, Baquero B, Duerksen S. Is parenting style related to children's healthy eating and physical activity in Latino families? Health Educ Res. 2006 Dec;21(6):862-71.

7. Birch LL, Fisher JO. Mothers' child-feeding practices influence daughters' eating and weight. Am J Clin Nutr. 2000 May;71(5):1054-61.

8. Hesketh K, Waters E, Green J, Salmon L, Williams J. Healthy eating, activity and obesity prevention: a qualitative study of parent and child perceptions in Australia. Health Promot Int. 2005 Mar;20(1):19-26.

9. Stanton B, Cole M, Galbraith J, Li X, Pendleton S, Cottrel L, et al. Randomized trial of a parent intervention: parents can make a difference in long-term adolescent risk behaviors, perceptions, and knowledge. Arch Pediatr Adolesc Med. 2004 Oct;158(10):947-55.

10. Vanhala ML, Keinanen-Kiukaanniemi SM, Kaikkonen KM, Laitinen JH, Korpelainen RI. Factors associated with parental recognition of a child's overweight status--a cross sectional study. BMC Public Health. 2011;11:665.

11. Johannsen DL, Johannsen NM, Specker BL. Influence of parents' eating behaviors and child feeding practices on children's weight status. Obesity (Silver Spring). 2006 Mar;14(3):431-9.

12. Eckstein KC, Mikhail LM, Ariza AJ, Thomson JS, Millard SC, Binns HJ. Parents' perceptions of their child's weight and health. Pediatrics. 2006 Mar;117(3):681-90.

13. Clark HR, Goyder E, Bissell P, Blank L, Peters J. How do parents' child-feeding behaviours influence child weight? Implications for childhood obesity policy. J Public Health (Oxf). 2007 Jun;29(2):132-41. 